While practising at cricket to-night (May 18 ), in splendid light, I observed at 7.58 (railway time) a very brilliant metenr cross the sky obliquely from a point considerably north of the zenith to the south.east. IIs movement was very slow, and it shone with a brilliant intense white light, which was concen. trated in itself, and did not leave a train behind it like the meteor of March 18, iS93, which I had also the good fortune to see.

It got gradually smaller and smaller, and just before disappearing broke up into three or four pear-shaped portions. During its course, although the massy head was always bril. liantly white, the little tail varied in hue, crimson and a rich ultramarine blue being most noticeable.

I immediatelv timed it, and found that it was about 13 seconds in view, which I thought a very long time indeed.

From diagrams made on the same evening, it seems that the meteor moved from a point $40^{\circ}$ from the zenith, and some $15^{\circ}$ west of north to a point about $30^{\circ}$ east of south at an altitude of $30^{\circ}$.

Muirkirk, Ayrshire, May 30.

JAS. G. Richaion.

P.S. - The head when first seen had an apparent diameter about $\frac{5}{5}$ that of the sun, and when last seen $\frac{3}{8}$ sun's diameter. It rolled actoss like a trall with a very short tail, until it broke up, when the distance from the head to the tail of the last pearshaped portion was about $3 \frac{1}{2}$ sun's diameter.

Iron Crows' Nests.

REFERRING to the note by Mr. McMillan, in your issue of May 3, it may be of interest to some of jour readers to know that we have in tbis museum a crow's nest from Rangoon entirely made of iron wire such as is used in fastening the corks of aërated water hottles. The donor, Mr. Joseph Dawson, of the Public Works Department, Rangoon, stated in his letter at the time that "wire nests are hardly a novelty in this country, as they can alwass be obtained from high trees in the vicinity of aërated water factories." The nest in question has a piece of hoop-iron about three or four inches long woven into it; but with that exception it is entirely composed of the small wire, and is about a foot in diameter.

Kelvingrove Nuseum, Glasgow, May 28 .

\section{THE REPORT OF THE COMMITTEE ON ARMY EXAMIINATIONS.}

$\mathrm{N}$ the Times of Wednesday, 23rd ult., there was a 1 brief account of the report lately presented to Parliament by the committee appointed in 1893 " to enquire into the entrance examinations (in non-military subjects) of candidates for commissions in the Army, and to advise whether any modification of the existing arrangements is desirable."

The syllabus of subjects and marks recommended by the committee is as follows:-

$$
\text { Class 1.-(All may be taken up.) }
$$

$\begin{array}{lccccr}\text { I. Mathematics ... } & \ldots & \ldots & \ldots & \ldots & 3000 \\ \text { 2. Geometrical Drawing... } & \ldots & \ldots & \ldots & 1000 \\ \text { 3. French or German } & \ldots & \ldots & \ldots & \ldots & 2000 \\ \text { 4. Englisb... } \ldots & \ldots & \ldots & \ldots & \ldots & 1000 \\ \text { 5. Freehand Drawing } & \ldots & \ldots & \ldots & \ldots & 500\end{array}$

ClasS II.-(Any three subjicts may be taken up, but for Woolwich one of the three must be Chemistry and Heat.)

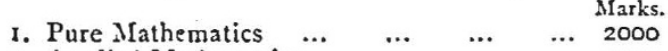

2. Applied Mathematics... $\quad \ldots \quad \ldots . \quad \ldots .2000$

3. German or French, as alternating with the $\begin{array}{llllll}\text { same group in Class I. } & \ldots & \ldots & \ldots & 2000\end{array}$

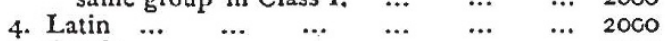

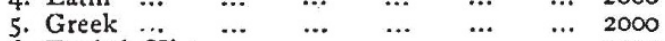

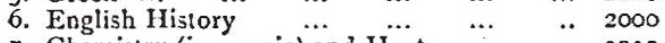

7. Chemistry (inorganic) and Hext $\ldots . \quad \ldots \quad 2000$

ช. Electricity and Magnetism and Light $\ldots .2000$

9. Geography, Political and Physical, and $\begin{array}{lllllll}\text { Geology } & \ldots & \ldots & \ldots & \ldots & \ldots & 2000\end{array}$

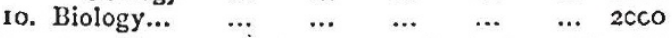

Certain recommendations as to the fusion of the Woolwich and Sandhurst examinations, the admission to the

No. $12 S_{4}$, vol. 50]
Army of Queen's cadets, Militia candidates, and University candidates are also made.

In regard to the question of marking for physical exercises and development, which has lately been strongly advocated, it is advised that these subjects should not be marked in these competitions. It seems to be thought, however, that though the physique of our officers has been well maintained under the competitive system, yet a small proportion of cadets have been admitted who were not quite up to the necessary standard, and it is recommended that the medical examination should be made somewhat more stringent.

The two changes of greatest importance which have been advised by the committee are, briefly, as follows -

(I) That an elementary knowledge of chemistry and heat shall be made practically obligatory for Woolwich.

(2) That Latin shall be transferred from Class I. to Class II.

There is also a minority report on certain points, viz., on the suggestion of a complete fusion of the competitions for Woolwich and Sandhurst, and on the proposal to transfer Latin to Class II. This is signed by three of the nine members of the committee, and one of these three also signs a separate note in which he dissents from the addition of geography to No. 9 of Class II., and of biology to Class 11. as a new subject, and makes certain proposals to meet the special needs of Woolwich (which he admits) that would certainly fail to effect their proposed purpose.

On May 29, this report, and especially the two recommendations relating to science for Woolwich, and to Latin, were vehemently attacked by the Times in an article in which the report was denounced as such an one as "might have been framed by a committee of crammers," so far as their probable effect is concerned, rather than by a committee which is unanimous in subscribing to the principle laid down in $1869-70$, that the examinations should be designed "with special reference to the curriculum adapted at the most advanced of our public schools, and with the express intention of enabling the competitors to come straight from one of those establishments to the examination-hall without having occasion to resort to any intermediate place of study." And again in a later paragraph, as a mere attempt by a portion of the committee to show themselves modern and advanced at all hazards by replacing the dead languages by the new sciences-Latin by chemistrywhich latter subject is pronounced to be the most easy of all to cram in face of the statistics, produced by the Civil Service Commissioners and printed with the report, which show the subject to be above the average in discriminating power-that is to say, one in which teachers have not succeeded, by cramming or in any other way, in raising the marks of the least apt to or near the level of those of the more apt.

The Times has not hesitated to accuse the majority of the committee of disregarding the evidence before them, but has itself committed this fault. Its case is indeed mainly founded on such disregard of the facts. By coupling together two changes which stand upon entirely different footings it creates the impression, and is itself apparently under the impression, that the committee was divided on both the above proposals. Nothing is plainer in the reports than that this was not the case.

From the same cause, a reader would gather from the Times that science is recommended as an obligatory subject for all Army candidates, whereas nothing of the sort has been proposed.

Then it ignores the fact that the opinions of head masters as expressed to the committee were almost entirely in favour of giving more weight to science in the case of Woolwich candidates. And finally, it seeks to give weight to the opinions of the minority of 
the committee by putting aside the opinion of the present Director-General of Military Education as that of a person of little present importance on this question, by ignoring the high classical acquirements of Mr. Roby, who is a distinguished scholar and the author of a standard Latin grammar, and by dismissing $\mathrm{Sir}$ Henry Roscoe, with his great educational experience on the Scotch University Commission and on other occasions, as though he were an ordinary Member of Parliament with no special experience or weight on a question of this kind. All these facts combine to make it important that we should place the matter fully and in a true light before our readers.

In order to form a just judgment on the recommendations of the committee, it is necessary to do just that which the Times has not done. Each of the proposed changes must be considered on its own merits, in relation to the other subjects, to the needs of the various branches of the Service, and to the present teaching powers of the most advanced public schools.

We must first point out that the recommendation that chemistry and heat shall be required in future from all Woolwich candidates stands upon a footing which is in many respects different, and altogether independent of that upon which the other recommendation stands.

In the first place, this recommendation is adopted by every member of the committee except one. And even he, in his dissent, admits that for Woolwich some degree of further specialising is necessary, and makes a recommendation for the purpose of effecting it. Unfortunately his proposal would pretty certainly fail of its purpose; it is quite unsound, and was, we think rightly, not adopted by the rest of the committee.

Secondly, it is not advised that science should be made a compulsory subject for the Army in the same sense as that in which Latin has of late years been compulsory. It is not proposed to require it of all candidates, but only of those who are admitted to the scientific branches.

These, we need hardly point out, form only a minority of the whole. No one need be kept out of the Army through ignorance of science, and those who are really strong in other subjects will not even be kept out of the Artillery and Engineers by this regulation if it be adopted.

Thirdly, as what follows will show, science for Woolwich was strongly supported by most of the head masters who assisted the committee with their opinions. Thus, Dr. Percival, of Rugby, included obligatory science in a scheme of examination which he offered for consideration, and said that he thought any school which is worth considering would bring its candidates up to a very fair level in science before they entered Woolwich or Sandhurst ; and explained that he meant not only the larger, but almost all schools.

The Rev. J. E. C. IVelldon, of Harrow, included a branch of science in a list of obligatory subjects which he considered should enter into the education of every English gentleman.

Mr. Phillpotts, of Bedford, did not advise compulsory science, but he expressed a wish that the chemistry marks should be raised to 2500 , which experience has shown in effect almost make this subject an obligatory one.

The head master of St. Paul's suggested in a letter that a branch of experimental science should be raised to Class I. with 2000 marks for Woolwich candidates.

The head master of IVestward Ho wrote that he believed that nothing short of the inclusion of a science among "obligatory subjects" will bring about satisfactory results.

The head master of Loretto placed science on his optional list; but said that but for geography he is not sure if some power of practical work should not be placed among the necessary subjects, and stated that he longs No. $128_{4}$, voL. 50] to see practical chemistry introduced into the regular curriculum of schools.

Only two head masters said nothing in support of science subjects for Woolwich. And finally, Prof. Jebb has lately expressed to the Secretary of State for WVar his opinion that the scientific study and the linguistic studies should be put on an equal footing in respect to these examinations.

With this evidence before them, with complaints alike from schools and on the part of the Professor of Experimental Science at Woolwich, of a waste of time and power there in regard to science teaching, which makes itself felt even in Class I., and which is inevitable under the present system, and with ample testimony to the increasing importance of science to the scientific branches, could any impartial body of advisers have made a more reasonable and more modest recom. mendation than that which the Army Examinations Committee has made to Parliament?

As regards the influence this change would have upon the curriculum of our "most advanced public schools," and the possibility that it may drive boys from the schools to the crammer, which our contemporary seems greatly to fear, what we wonder would be said by Rugby, Cheltenham, Clifton, Marlborough, St. Paul's, or by Westward Ho, Malvern, Dover, and a score of other schools, if it were suggested to them that their appliances for and power of teaching science were inferior to those of the private tutors? It is notorious that the contrary is the case, that for long past the schools have held more than their own in these respects, and that the school of moderate size that is not now able to give good elementary instruction in chemistry and heat, is so far from being amongst our most advanced schools that it must be pronounced to be one that is unmistakably behind the times.

Finally, the selection of subjects made by the committee is not only a good one, but under the circumstances seems the best that could be made. It will not discourage either chemistry or physics entirely in the schools, and there areschools which prefer each of these branches; it is within the scope of the resources of all thoroughly efficient schools, which some other selections might not have been; and, aboveall, since it corresponds well with the elementary courses of instruction that have been in force at Woolwich, it will best avoid the loss of time there, which has been already alluded to, and will permit the cadets at once to proceed to those sciences of which they will need a technical and advanced knowledge, such as electricity and the chemistry of explosives, and for which more time and a better state of preparedness at entrance is said to be greatly wanted.

The recommendation to place Latin in Class II., as we have said, needs separate consideration. It must be admitted that there was a considerable body of evidence against it, and a division of opinion on the subject among the members of the committee. The question is one of great difficulty. It would have been impossible to retain compulsory Latin for Sandhurst without practically compelling it for Woolwich also. All who are experienced in these examinations will admit this. But to have retained it for Woolwich would have tended very greatly to limit the range of subjects taken by these cadets. It cannot be said that Latin is professionally an essential subject for Army candidates, as a few others are ; and even the Times admits that possibly its study may not be "an ideal whetstone of the mind," whilst it is certain that a good many youths do not appear to gain much from it after boyhood is past. Its early introduction into education, and its retention up to a certain point, are, on the other hand, widely thought to be among the best features of the public school system. There is also a feeling that it serves as an excellent introduction to the study of languages, and doubtless it does so when well taught. But 
these facts, though they afford a strong reason for avoiding any step which would really be likely to prevent the teaching of Latin in the lower forms of public schools, seem to be an insufficient reason for compelling those who do not get on with the subject to continue to study it up to the age of eighteen or nineteen years, when by dropping it in reasonable time they might turn to some, for them, more profitable study. It is often forgotten that when all boys learnt Latin and Greek and little else, but few of them stayed at school so late as great numbers do at present, and that therefore there is less reason for resisting a change in this direction now than there would have been in the days mentioned by General Sir G. T. Chesney, when cadets might enter Woolwich at the age of fourteen or fifteen years.

On the whole, therefore, our feeling is that the recommendation of the majority on this point goes in the right direction. The general position of Latin in the schools will surely be sufficiently protected by the action of the universities, and hence its serious discouragement need not be greatly feared. WVe would ask, however, whether the objections of the dissentient members of the committee could not be met by a requirement that all candidates should take for one of their subjects from Class II. a language. This would distinctly protect linguistic studies in the schools, and so act distinctly in favour of Latin, without compelling all candidates to offer
Latin, or handicapping any school which may prefer not to teach it in all its divisions. It has been said that the difficulty of Latin will prevent its being much adopted as a voluntary subject. Surely this must mean that too high a standard has been adopted for the circumstances of these candidates who cannot of course reach to the level of the higher classical forms. The Civil Service Commissioners should and could prevent any such unfairness as this from occurring, and therefore could prevent the subject from being killed, which surely all would regret.

RECENT ADDITIONS TO THE ZOOLOGICAL SOCIETY'S MENAGERIE.

A LTHOUGH it becomes more difficult year by year A for the Zoological Society to add new objects to their collection of living animals, yet, as is shown by the annual reports read at the anniversary meetings, examples of a certain number of species which have not been "previously exhibited" are acquired every year. In $\mathrm{I} 892$, as we are told in last year's report, specimens of II manmals, 20 birds, I4 reptiles, and one batrachian "referable to species not included in the last (eighth) edition of the "List of Animals," were added to the series. In I $\$ 93$, the numbers of novelties in the respective classes were hardly less numerous.

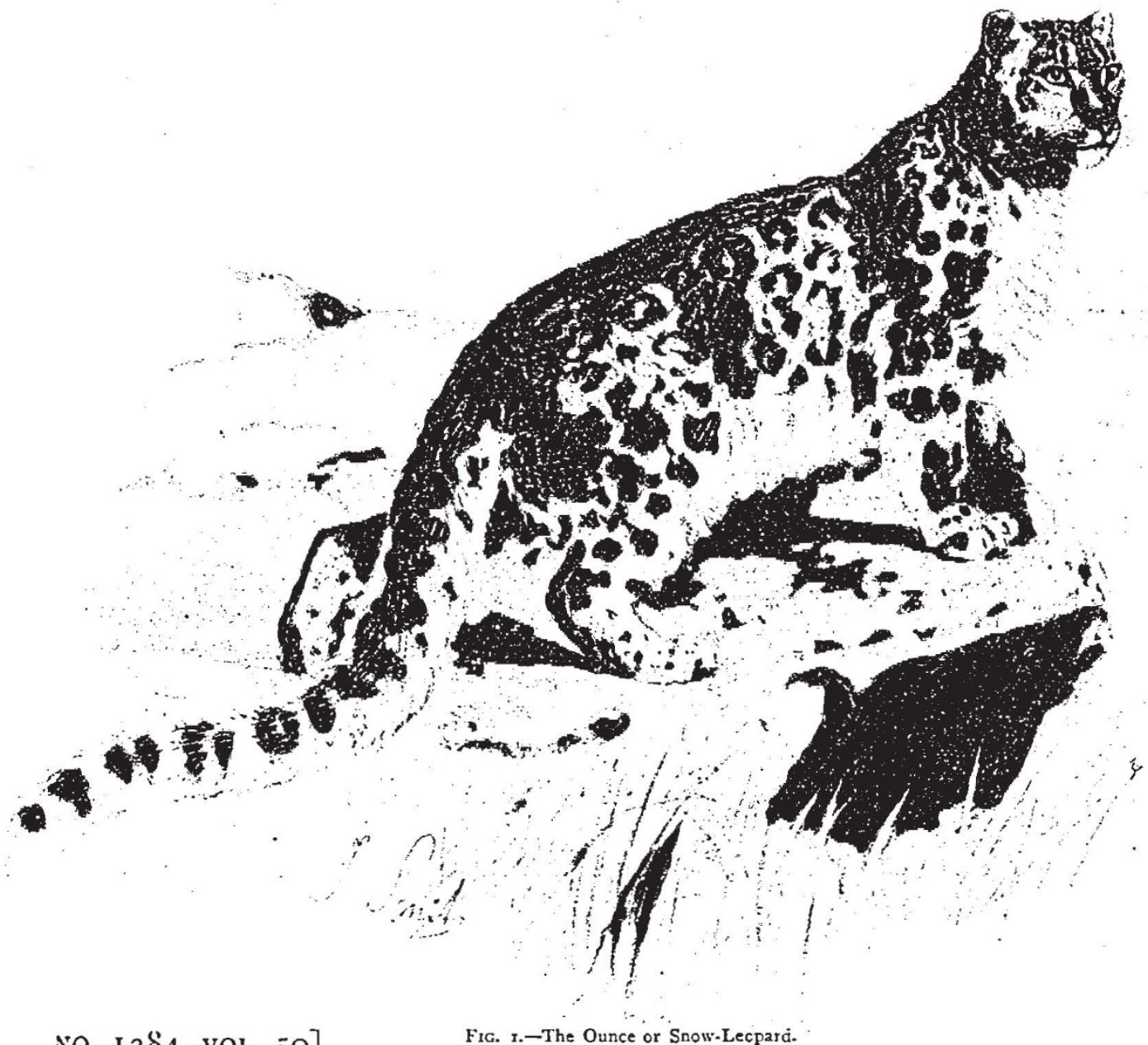

ก. I 284 , vo1.. jo]

Fig. r.-The Ounce or Snow-Lecpard. 